and UCB Pharma, Lennart T.H. Jacobsson Consultant of: AbbVie, Eli Lilly, Janssen, Novartis and Pfizer

DOI: 10.1136/annrheumdis-2020-eular.960

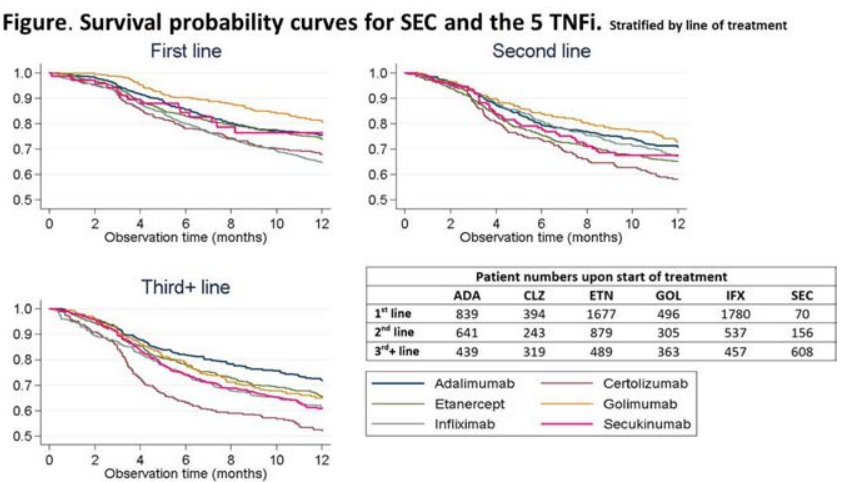

\section{FRI0276 \\ EARLY TREATMENT WITH ANTI-TNF IS ASSOCIATED WITH HIGHER RESPONSE RATES IN PATIENTS WITH ACTIVE AXSPA}

S. Gulle ${ }^{1}$, İ. Sari ${ }^{1}$, E. Durak Ediboglu ${ }^{2}$, H. Candan ${ }^{3}$, F. Onen ${ }^{1}$, S. Akar ${ }^{2} .{ }^{1}$ Dokuz Eylul University Hospital, Internal Medicine, Rheumatology, Izmir, Turkey; ${ }^{2}$ Izmir Katip Çelebi University, Internal Medicine, Rheumatology, Izmir, Turkey; ${ }^{3}$ Dokuz Eylul University, Department of Statistics, Data Science, İzmir, Turkey

Background: Treatment options for axial spondyloarthritis (axSpA) is currently limited, and up to $40 \%$ of the patients require biologic therapies to control symptoms. Early commencement of biologics suggested to have higher response rates but data regarding this subject is limited.

Objectives: The primary aim was to investigate tumor necrosis factor inhibitor (TNFi) response and retention rates in axSpA patients who were treated in the early disease period (symptom duration ( $\leq 5$ years). Our secondary aim was to identify factors predicting response to TNFi.

Methods: Adult axial SpA patients who started TNFi treatments within the five years of their symptoms were identified and defined as "Group 1." Patients whose TNFi treatments started five years after their initial symptoms served as a control group (Group 2: 5-10 years and Group3: $\geq 10$ years). Response and survival rates at 6,12 , and 24 months were calculated. Predictors of response on TNFi survival at 24 months were also analyzed.

Results: There was a total of 364 axiSpA (Group 1: 95, Group 2: 82 and Group 3: 187$)$ patients in the study (69.8\% male, $46.8 \pm 12.6$ years). Group 1 patients tended to be younger, with a lower baseline CRP titers and lower HLA-B27 rate compared to the other groups. Drug survival rates were similar between the groups. This finding also remained similar when AS and nraxSpA patients analyzed separately. However, regardless of symptom duration, the drug retention rates were significantly higher in the AS group than in nraxSpA (Table 2). ASAS40 responses were higher in Group 1 than in Group 3 both at 12 and 24 months. Predictors of response based on ASAS40 at 24 months were treatment within the five years of the symptoms (OR:2.2) and age at baseline (OR:0.97) in univariate analysis. However, baseline ASDAS (OR:1.4) was the only factor in multiple regression.

Conclusion: In this study we showed the following: 1) TNFi started in the early disease course resulted in a better ASAS40 response at both 12 and 24 months, 2) TNFi timing (started in the early or late disease period) seems not affecting drug retention rates, and 3 ) baseline disease activity is the most important predictor in achieving ASAS40 response at 24 months.

Disclosure of Interests: None declared

DOI: 10.1136/annrheumdis-2020-eular.4113

\section{FRI0277 EFFECTIVENESS OF BDMARDS IN AS AND NR-AXSPA PATIENT POPULATIONS: EXPERIENCE FROM THE CORRONA REGISTRY}

T. Hunter $^{1}$, T. Blachley ${ }^{2}$, W. Malatestinic ${ }^{1}$, L. Harrold ${ }^{2}$, B. Dube ${ }^{2}$, M. Glynn ${ }^{2}$, J. Lisse ${ }^{1,3}$, R. Bolce ${ }^{1}$, P. J. Mease ${ }^{4}$. ${ }^{1}$ Lilly, Indianapolis, United States of America; ${ }^{2}$ Corrona, Waltham, United States of America; ${ }^{3}$ Eli Lilly and Company, Indianapolis, United States of America; ${ }^{4}$ University of Washington, Seattle, United States of America

Background: Axial spondyloarthritis (axSpA) consists of ankylosing spondylitis (AS), also referred to as radiographic $\operatorname{axSpA}(r-a x S p A)$ and non-radiographic
Table 1. Demographic characteristics and clinical response rates of AxSpA patients

\begin{tabular}{|c|c|c|c|c|}
\hline & $\begin{array}{c}\leq 5 \text { years }(A) \\
\text { (Group } 1)\end{array}$ & $\begin{array}{c}\text { 5-10 year (B) } \\
\text { (Group 2) }\end{array}$ & $\begin{array}{c}\geq 10 \text { years }(C) \\
(\text { Group } 3)\end{array}$ & $\mathbf{P}$ \\
\hline & $(n=95)$ & $(n=82)$ & $(n=187)$ & \\
\hline & Mean $\pm S D$ & Mean \pm SD. & Mean \pm SD. & \\
\hline Age (year) & $39,9 \pm 12,9^{\mathrm{BC}}$ & $44,9 \pm 11,0^{\mathrm{c}}$ & $51,0 \pm 11,4$ & $<0,001$ \\
\hline \multirow{2}{*}{$\begin{array}{l}\text { BASDAI } \\
\text { (baseline) }\end{array}$} & $51,1 \pm 19.9$ & $56,2 \pm 18,2$ & $54,4 \pm 20,0$ & 0,133 \\
\hline & n (\%) & n (\%) & n (\%) & \\
\hline Gender, Male & $70(73,7)$ & $52(63,4)$ & $132(70,6)$ & 0,346 \\
\hline \multirow[t]{2}{*}{ Diagnosis, AS } & $60(63,8)^{c}$ & $63(76,8)^{\mathrm{C}}$ & $170(90,4)$ & $<0,001$ \\
\hline & Median (Min./Max.) & Median (Min./Max.) & Median (Min./Max.) & \\
\hline CRP (baseline) & $\begin{array}{c}10(0 / 140)^{c} \\
n(\%)\end{array}$ & $\begin{array}{c}9,75(0,4 / 95) \\
\text { n (\%) }\end{array}$ & $\begin{array}{c}13(0 / 177) \\
n(\%)\end{array}$ & 0,049 \\
\hline HLAB27 (+) & $52(54,7)$ & $46(56,1)$ & $127(67,9)$ A & 0,007 \\
\hline \multicolumn{5}{|l|}{ ASAS 40} \\
\hline $6^{\text {th }}$ Month & $42(45,7)$ & $36(46,8)$ & $76(42,7)$ & 0,611 \\
\hline $12^{\text {th }}$ Month & $59(68,6)^{c}$ & $45(62,5)$ & $94(55,0)$ & 0,032 \\
\hline $24^{\text {th }}$ Month & $34(63,0)^{c}$ & $24(50,0)$ & $49(45,4)$ & 0,042 \\
\hline \multicolumn{5}{|l|}{ ASDAS-CRP MI } \\
\hline $6^{\text {th }}$ Month & $42(46,2)$ & $36(48,0)$ & $66(37,3)$ & 0,568 \\
\hline $12^{\text {th }}$ Month & $40(47,6)$ & $38(53,5)$ & $83(48,5)$ & 0,788 \\
\hline $24^{\text {th }}$ Month & $29(53,7)$ & $19(38,8)$ & $44(40,7)$ & 0,738 \\
\hline
\end{tabular}

OneWay ANOVA (Robuts Statistic:Brown-Forsythe)

Table 2. TNFi drug survival rate results of early and late disease course

\begin{tabular}{|c|c|c|c|c|}
\hline & $\begin{array}{l}\text { TNFi retention } \\
\text { rates ( } 24 \text { months) }\end{array}$ & $\begin{array}{l}\text { Follow-up } \\
\text { period (month) }\end{array}$ & $\begin{array}{l}\text { Proportion of Drug } \\
\text { ) Retention Rate (month) }\end{array}$ & $\mathbf{P}$ \\
\hline & $n(\%)$ & Median \pm Se & $6 / 12 / 24$ & \\
\hline Symptom duration, & & & & 0.203 \\
\hline \multicolumn{5}{|l|}{ Disease } \\
\hline$\leq 5$ years, AS & $34(75,6)$ & $80,0 \pm 14,4$ & $93,2 / 86 / 75,6$ & \\
\hline$\leq 5$ years, $\mathrm{nrAxSpA}$ & $18(58,3)$ & $36,0 \pm 11,9$ & $91,2 / 64,6 / 58,3$ & \\
\hline $5-10$ years, AS & $38(61,7)$ & $57,0 \pm 25,0$ & $92,1 / 81 / 61,7$ & \\
\hline 5-10 years, $\mathrm{NrAxSpA}$ & $8(44,9)$ & $23,0 \pm 4,2$ & $89,5 / 73 / 44,9$ & \\
\hline$\geq 10$ years, AS & $119(72,1)$ & $52,0 \pm 4,0$ & $92,4 / 85,9 / 72,1$ & \\
\hline$\geq 10$ years, $\mathrm{NrAxSpA}$ & $11(61,1)^{\prime}$ & $37,0 \pm 7,6$ & $88,9 / 66,7 / 61,1$ & \\
\hline \multicolumn{5}{|l|}{ Diagnosis } \\
\hline nrAxSpA & $37(55,7)$ & $37,0 \pm 7,6$ & $84,6 / 67,3 / 55,7$ & $<0,001$ \\
\hline AS & $193(70,6)$ & $59,0 \pm 6,5$ & $90,1 / 84,2 / 70,6$ & \\
\hline
\end{tabular}

Kaplan Meier Test; Log Rank (Mantel-Cox)

$\operatorname{axSpA}(n r-a x S p A)$. AxSpA can lead to reduced mobility, pain, fatigue, and impact quality of life. While bDMARDs are available for treatment, the literature lacks studies exploring their real-world effectiveness in clinical registry patients with $\operatorname{axSpA}$.

Objectives: To describe patient characteristics of bDMARD initiators among the AS and nr-axSpA populations and the effectiveness of bDMARDs at the 6-month $( \pm 3$ ) post-initiation follow-up (FU) visit in the Corrona PsA/SpA Registry.

Methods: This study included patients aged $\geq 18$ years with AS per modified NY criteria and nr-axSpA per ASAS criteria enrolled between 3/2013 and 9/2019. Concurrently diagnosed patients with PsA were excluded. Baseline characteristics, such as demographic, clinical, disease activity, treatment, and patient-reported outcomes (PRO), were collected for those initiating a bDMARD at enrollment or during $\mathrm{FU}$; response rates and mean change in disease activity and PRO between initiation and 6-month FU were calculated

Results: The AS $(n=179)$ and $n r-a x S p A(n=32)$ bDMARD initiators groups were similar at initiation for mean age (AS: $49.1 \mathrm{yrs}, \mathrm{nr}$-axSpA: $48.9 \mathrm{yrs}$ ), ASDAS scores (AS: 2.9, nr-axSpA: 2.8) and patient global assessment (AS: 59.6, nr-ax$\mathrm{SpA}:$ 60.0). The two groups were different for time from disease duration (AS 8.5 yrs, nr-axSpA, 6.6 yrs), current NSAID use (AS: $64.2 \%$, nr-axSpA: $46.9 \%$ ) and naivete to cDMARDS (AS: $70.4 \%$, nr-axSpA: $40.6 \%$ ), TNFs (AS: $47.5 \%$, nr-axSpA: $21.9 \%$ ), non-TNFs (AS: $96.1 \%$, nr-axSpA: 93.8\%) and bDMARDs (AS: $46.9 \%$, nr-axSpA: $21.9 \%$ ). Patients were similarly impacted by their condition for BASDAI (AS: 5.0, nr-axSpA, 5.6), pain (AS: 55.8, nr-axSpA, 60.8) and fatigue (AS: 51.6, nr-axSpA, 59.9), but there was an imbalance in tender joint count (AS: 2.6, nr-axSpA, 13.4).

At 6-month FU, both populations experienced minimal or no change in ASDAS scores (AS: -0.3 , nr-axSpA: 0.0 ) remaining in a high state of disease activity (ASDAS, 22.2). A small percent of both groups achieved ASAS20 (AS: $20.1 \%$; nr-axSpA: $21.9 \%$ ) and ASAS40 (AS: $14 \%$, nr-axSpA: 15.6\%). Further, bDMARD initiators had minimal decreases in BASDAI (AS: -0.6, nr-axSpA: -0.8), pain (AS: -8.5, nr-axSpA: -12.2), and fatigue (AS: -5.0, nr-axSpA: -7.9) scores. 